\title{
Hypoxia-inducible factors and diabetes
}

\author{
Jenny E. Gunton 1,2,3 \\ ${ }^{1}$ Centre for Diabetes, Obesity and Endocrinology, Westmead Institute for Medical Research, Westmead, New South Wales, Australia. ${ }^{2}$ Westmead Hospital, Faculty of Medicine and Health, The University of \\ Sydney, Sydney, New South Wales, Australia. ${ }^{3}$ Garvan Institute of Medical Research, Darlinghurst, New South Wales, Australia.
}

\begin{abstract}
Hypoxia can be defined as a relative deficiency in the amount of oxygen reaching the tissues. Hypoxia-inducible factors (HIFs) are critical regulators of the mammalian response to hypoxia. In normal circumstances, HIF-1 $\alpha$ protein turnover is rapid, and hyperglycemia further destabilizes the protein. In addition to their role in diabetes pathogenesis, HIFs are implicated in development of the microvascular and macrovascular complications of diabetes. Improving glucose control in people with diabetes increases HIF-1 $\alpha$ protein and has wide-ranging benefits, some of which are at least partially mediated by HIF-1 $\alpha$. Nevertheless, most strategies to improve diabetes or its complications via regulation of HIF-1 $\alpha$ have not currently proven to be clinically useful. The intersection of HIF biology with diabetes is a complex area in which many further questions remain, especially regarding the well-conducted studies clearly describing discrepant effects of different methods of increasing HIF$1 \alpha$, even within the same tissues. This Review presents a brief overview of HIFs; discusses the range of evidence implicating HIFs in $\beta$ cell dysfunction, diabetes pathogenesis, and diabetes complications; and examines the differing outcomes of HIFtargeting approaches in these conditions.
\end{abstract}

\section{Introduction}

Diabetes prevalence is rising rapidly. In 2017 it was estimated that there were more than 450 million people with diabetes worldwide (1). Diabetes is the major cause of preventable blindness, endstage renal failure, and preventable lower limb amputations (2). It is also associated with increased cardiovascular disease risk and decreased life expectancy (3).

Insulin is the major hormone produced from $\beta$ cells in the pancreatic islets of Langerhans. It lowers blood glucose by stimulating uptake into tissues including muscle and fat. Glucose transporter 4 (GLUT4) is responsible for most of this effect (4-6). In type 1 diabetes (T1D) and type 2 diabetes (T2D), there is not enough insulin to regulate blood glucose. In T1D, $\beta$ cells are lost as a result of autoimmune-mediated destruction $(7,8)$. In T2D, $\beta$ cells cannot release enough insulin to control glucose due to loss of cells, poor function, or both. Obesity increases risk for T1D (9) and T2D (10-12) in part by reducing insulin sensitivity; that is, insulin does not produce a normal decrement in blood glucose.

Hypoxia can be defined as deficiency in the amount of oxygen reaching target tissues. All mammals have processes to sense, respond to, and correct hypoxia. The most important component of this response is mediated by the hypoxia-inducible factors (HIFs).

\section{Basic helix-loop-helix-PER-ARNT-SIM transcription factors}

HIFs are part of the basic helix-loop-helix-PER-ARNT-SIM (bHLH-PAS) family. These transcription factors function as obligate heterodimers with a class I plus a class II family member (ref. 13 and Figure 1A). Class I members include HIF-1 $\alpha$, endothelial

Conflict of interest: The author has declared that no conflict of interest exists. Copyright: @ 2020, American Society for Clinical Investigation.

Reference information: J Clin Invest. 2020;130(10):5063-5073.

https://doi.org/10.1172/JCI137556.
PAS domain protein 1 (EPAS1; also called HIF-2 $\alpha$ and member of PAS superfamily 2 [MOP2]), inhibitory PAS domain protein (IPAS; previously called HIF-3 $\alpha$ ), aryl hydrocarbon receptor (AhR), single-minded 1 and 2 (SIM1 and SIM2), circadian locomotor output cycles kaput protein (CLOCK), and neuronal PAS proteins 1-3 (NPAS1-NPAS3). IPAS has inhibitory effects on HIF- $1 \alpha$ and HIF- $2 \alpha$ and will not be discussed extensively in this Review, as it has no known role in diabetes. Class II members include aryl hydrocarbon receptor nuclear translocator (ARNT; also called HIF-1 $\beta$ ), ARNT2, and bone morphogenetic ARNTlike 1 (BMAL1) and BMAL2.

\section{Hypoxia-inducible factor $1 \alpha$}

The HIF-1 transcription factor is formed by heterodimerization of HIF- $1 \alpha$ and HIF- $1 \beta(14,15)$. The first papers to describe the role of HIF-1 in hypoxic responses were the seminal 1992 and 1993 papers by Wang and Semenza $(16,17)$. In Hep3B cells, they described a nuclear factor with increased DNA-binding activity to the erythropoietin gene promoter after exposure to hypoxia.

Adequate oxygen is essential for numerous metabolic processes, including mitochondrial generation of energy from glucose (stored as ATP) (18). HIF-1 $\alpha$ is essential for normal development; the whole-body knockout is embryonic lethal, with abnormal placental development and cardiac and vascular anomalies (19).

In the short term, humans respond to hypoxia by cells in the carotid body sensing lower oxygen and driving increased respiration. Carotid body function is reviewed in ref. 20. The heterozygous HIF-1 $\alpha$-null mouse demonstrates that HIF-1 has a critical role in carotid body development (21). HIFs are also the most important factors in mediating medium- to long-term responses to hypoxia.

With its critical role in oxygen sensing and hypoxia responses, it is not surprising that HIF- $1 \alpha$ is regulated by many factors (22-29). In unstressed cells, HIF-1 $\alpha$ is synthesized, but the protein has a half-life of seconds to minutes (30). In the presence 
A

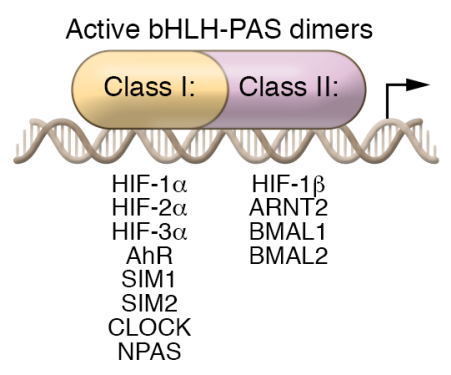

B

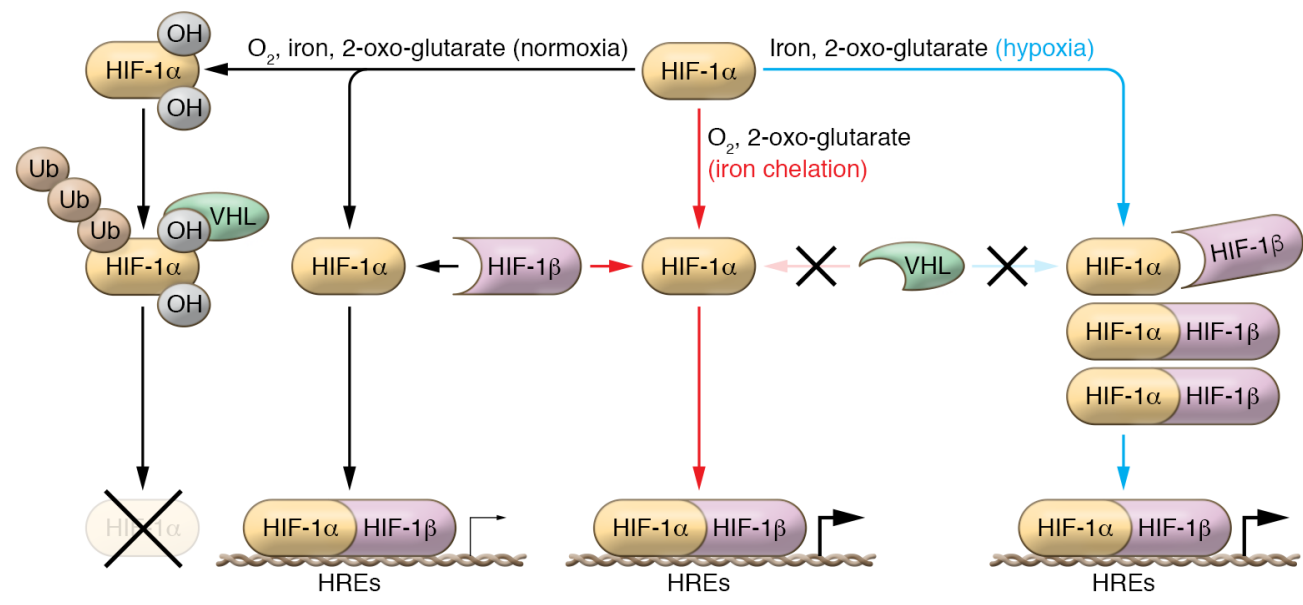

Figure 1. bHLH-PAS family and HIF-1 protein. (A) Basic helix-loop-helix-PER-ARNT-SIM (bHLH-PAS) family proteins work as heterodimers with a class I and a class II member. (B) HIF-1 $\alpha$ protein is regulated by iron and oxygen availability. In the presence of adequate oxygen, iron, and 2-oxo-glutarate (normoxia, left), little HIF-1 $\alpha$ escapes rapid hydroxylation $(\mathrm{OH})$, ubiquitination (Ub) by von Hippel-Lindau protein (VHL), and proteolysis. With deficiency of iron (middle) or oxygen (right), HIF-1 $\alpha$ protein accumulates and binds to HIF-1 $\beta$, and then the dimer binds to hypoxia response elements (HREs) to regulate gene expression. HIF, hypoxia inducible factor; AhR, aryl hydrocarbon receptor; SIM, single-minded; CLOCK, circadian locomotor output cycles kaput protein; NPAS, neuronal PAS protein; ARNT, aryl hydrocarbon receptor nuclear translocator; BMAL, bone morphogenetic ARNT-like.

of oxygen, iron, and 2-oxo-glutarate ( $\alpha$-ketoglutarate), HIF- $1 \alpha$ is hydroxylated on two proline residues (amino acids 402 and 564 of human HIF-1 $\alpha$ ) by prolyl hydroxylase domain (PHD) proteins, also called $\mathrm{P} 4 \mathrm{H}$ proteins (31). These PHDs function as oxygen sensors to regulate HIF degradation (Figure 1B). Another layer of regulation is provided by enzymatic asparagine hydroxylation by a factor inhibiting HIF (FIH). Hydroxylated HIF-1 $\alpha$ is bound by von Hippel-Lindau (VHL) protein, leading to its ubiquitination and proteolysis (32). That interaction is inhibited by cobalt. Absence of sufficient oxygen, iron, or 2-oxo-glutarate inhibits hydroxylation and thereby inhibits degradation. Similarly, lack of PHDs, FIH, or VHL impairs HIF-1 $\alpha$ degradation.

Unproteolyzed HIF-1 $\alpha$ binds to HIF-1 $\beta$ (Figure 1B), which facilitates translocation to the nucleus, recruitment of transcriptional coregulators, and regulation of gene expression.

\section{HIF-1 $\alpha$ and diabetes}

Our work has found that HIF1B mRNA is decreased in islets from people with T2D and is important for normal $\beta$ cell function (33, 34). That work showed that the bHLH-PAS family could regulate insulin secretion. With the heterodimeric composition of the active transcription factors, these findings led us to consider the partner or partners that are important for $\beta$ cell function. We discovered that deletion of HIF- $1 \alpha$ in $\beta$ cells caused glucose intolerance in mice due to impaired glucose-stimulated insulin secretion (35). The role of HIF- $1 \alpha$ in $\beta$ cell function and survival was also shown by observations of improved glucose tolerance in mice fed a high-fat diet plus an iron chelator to increase HIF-1 $\alpha$ protein stability (36). Improved glucose tolerance was due to better $\beta$ cell function. There was no beneficial effect of iron chelation on $\beta$ cell function in mice with $\beta$ cell-specific deletion of HIF- $1 \alpha$.

Islets, and more particularly $\beta$ cells, "sense" glucose by metabolizing it to generate increased ATP. This sensing requires cellular glucose uptake followed by metabolism. Deletion of HIF-1 $\alpha$ in $\beta$ cells decreased basal and glucose-stimulated ATP concentrations (35). Lower ATP generation, even when glucose is elevated, provides a mechanism for impaired glucose-stimulated insulin secretion with decreases in expression of the HIF-1 transcription factor. Higher intracellular ATP leads to closure of the inwardly rectifying potassium channel Kir6.2 and triggers the opening of voltage-dependent calcium channels in $\beta$ cells, especially L-type channels. The resulting calcium influx stimulates insulin vesicle fusion with the plasma membrane and insulin release.

First-phase insulin release is defined as release of insulin within 10 minutes of a stimulus. The second phase of insulin release occurs after 10 minutes. First-phase secretion is important for maintenance of normal glucose tolerance. Loss of first-phase release predicts future development of T1D and T2D (37-40). Mice lacking HIF- $1 \alpha$ in $\beta$ cells have pronounced loss of first-phase insulin release (35). Interestingly, loss of $\beta$ cell HIF-1 $\alpha$ increases risk of T1D. NOD mice (a model of T1D) have low rates of diabetes development after exposure to the $\beta$ cell toxin streptozotocin or to viruses associated with human diabetes (41). In NOD mice, loss of HIF- $1 \alpha$ in $\beta$ cells makes $\beta$ cells more susceptible to death, increasing the risk of spontaneous T1D and the risk of T1D after streptozotocin or coxsackievirus exposure (41).

Increasing HIF-1 $\alpha$ has differing effects on glucose tolerance depending on the method used, and these various outcomes are discussed below.

Glucose metabolism and HIF-1 $\alpha$. Although prolyl hydroxylases require 2-oxo-glutarate for activity, their regulation is more complex; other tricarboxylic acid intermediates (succinate and fumarate) compete with 2-oxo-glutarate for the binding pocket of PHDs and inhibit their function (42), permitting HIF-1 $\alpha$ stability. Pyruvate also inhibits PHD-mediated hydroxylation of HIF-1 $\alpha$, thereby increasing protein availability (43). 


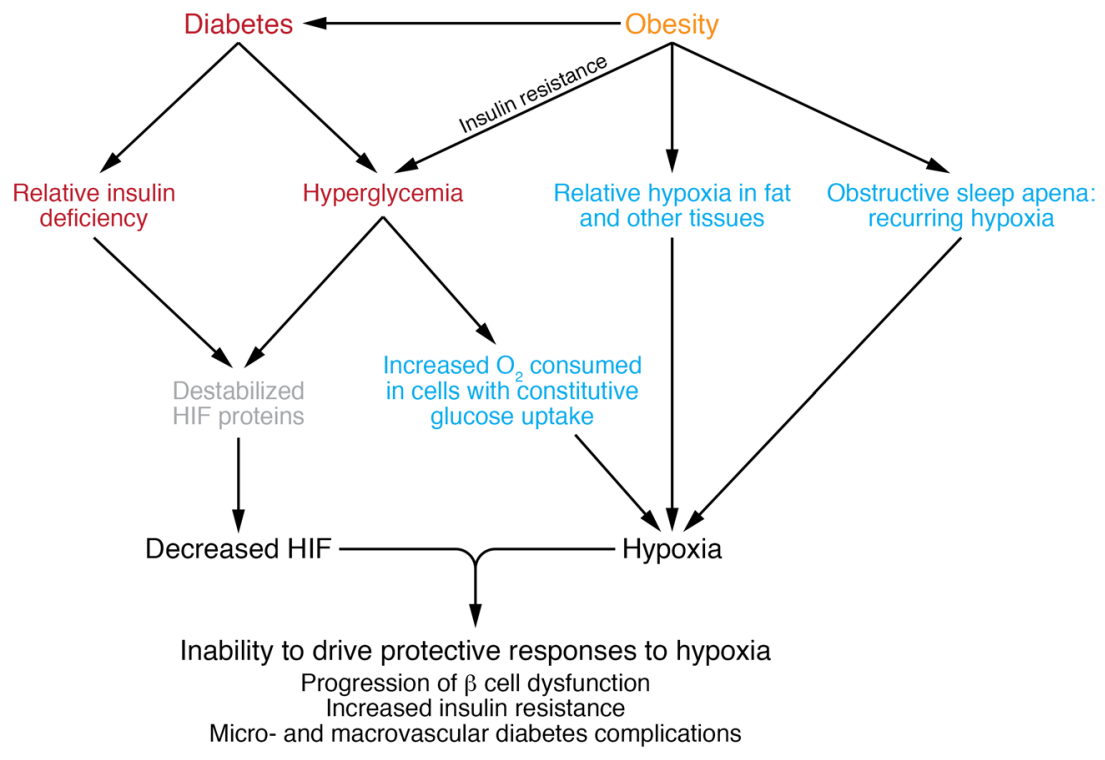

Figure 2. Interactions between diabetes, obesity, and HIFs. Insulin resistance and deficiency in diabetes are associated with destabilization of HIF proteins. While obesity exacerbates insulin resistance, it also promotes tissue hypoxia as well intermittent hypoxia through its association with sleep apnea. These concurrent outcomes mediate complex effects on diabetes progression and complications.
Together, these effects might be predicted to increase HIF$1 \alpha$ availability with hyperglycemia. However, the opposite occurs. Once $\beta$ cell dysfunction is present, glucose rises, and HIF- $1 \alpha$ protein is destabilized (44). Destabilization of HIF-1 $\alpha$ in diabetes is reviewed in detail in ref. 45 . Briefly, increases in 2-methylglyoxal that accompany hyperglycemia stimulate HIF-1 $\alpha$ degradation and inhibit transcriptional activity. 2-Methylglyoxal inhibits HIF$1 \alpha$-HIF-1 $\beta$ dimer formation and recruitment of the p300/CBP regulatory complex (45). Thus, overall, hyperglycemia reduces HIF- $1 \alpha$ activity.

Because lack of HIF- $1 \alpha$ has been associated with decreased $\beta$ cell function and survival, glucose-induced inhibition of HIF-1 $\alpha$ protein stability is also likely to hasten deterioration in $\beta$ cell function and speed progression to diabetes (Figure 2).

Insulin signaling and HIF-1 $\alpha$. In addition to the effects of glucose and its metabolites, insulin signaling upregulates HIF- $1 \alpha$ via $\mathrm{PI} 3 \mathrm{~K}$ and MAPK phosphorylation pathways. Insulin resistance is present in at least $80 \%$ of people with $\mathrm{T} 2 \mathrm{D}$, and impaired insulin signaling would therefore contribute to the decreased HIF- $1 \alpha$ seen in diabetes (35). Insulin deficiency associated with $\beta$ cell dysfunction or death would further decrease HIF- $1 \alpha$ in the setting of diabetic hyperglycemia.

Lipids and HIF-1 $\alpha$ and $\beta$ cell function. In addition to glucose effects on $\beta$ cell function (often called glucotoxicity) and HIF-1 $\alpha$ protein stability, lipids affect both $\beta$ cell function (lipotoxicity) and HIF-1 $\alpha$ (46). Metabolism of fatty acids, and particularly palmitate, causes decreased succinate. Succinate inhibits prolyl hydroxylation of HIF- $1 \alpha$, so decreased succinate permits increased HIF- $1 \alpha$ proteolysis. This is also consistent with the hypothesis that glucolipotoxicity accounts for the increased prevalence of diabetes seen in obesity.

\section{HIF-1 $\alpha$ in metabolically important tissues}

In addition to changes in $\beta$ cell function and gene expression seen with $\beta$ cell-specific deletion of HIF- $1 \alpha$ and with HIF- $1 \alpha$ knockdown $(35,41)$, HIF-1 $\alpha$ dysfunction is implicated in many of the metabolically important tissues and in many chronic complications of diabetes, discussed below.
$H I F-1 \alpha$ in muscle. Muscle is the most important tissue in the body for insulin-stimulated glucose uptake, and therefore muscle plays an important role in developing insulin resistance $(18,47$, 48). Insulin increases GLUT4 translocation to the myocyte cell membrane $(5,6)$. Muscle contraction during exercise increases oxygen utilization, leading to muscle hypoxia and HIF-1 $\alpha$ protein induction $(49,50)$.

Exercise and/or hypoxia in muscle increases glycolysis, and chronic hypoxia can decrease mitochondrial content, with a larger proportion of energy supply presumed to derive from glycolysis (51). Together with muscle contraction, HIF-1 $\alpha$ is important in maintenance of muscle function and metabolism with hypoxia (49). However, HIF-1 $\beta$ is apparently dispensable for normal muscle fiber type determination and insulin sensitivity, suggesting that an alternate HIF-1 $\alpha$ partner is active in muscle (52).

Knockdown of HIF-1 $\alpha$ in C2C12 cultured myocytes impairs GLUT4 translocation and glucose uptake (53). Mice with muscle-specific HIF-1 $\alpha$ deletion have a shift from glycolysis with lactate export during exercise toward full oxidation of glucose, but at a long-term cost of extensive muscle damage (54). When young, they have improved exercise capacity, but this reverses as muscle damage sets in.

The MRL/Mpj strain of mice exhibits enhanced muscle function that is dependent on HIF- $1 \alpha$ (55). In mouse models, increasing HIFs by inhibiting PHDs improves the muscle response to exercise-induced injury (56) and to cryoinjury (57). In humans, the Pro582Ser polymorphism produces HIF-1 $\alpha$ that is relatively degradation-resistant, increasing HIF- $1 \alpha$ activity. This polymorphism is present at increased frequency in athletes, particularly elite endurance athletes (58).

Similar to observations in $\beta$ cells, increasing HIF- $1 \alpha$ with hypoxia or VHL deletion has deleterious effects on muscle, but increasing HIF-1 $\alpha$ with FIH or PHD deletion appears beneficial (59). Together, the data indicate that myocyte HIF-1 $\alpha$ is necessary for normal muscle glucose uptake, insulin sensitivity, and prevention of muscle injury. With those features, it is surprising that there appear to be few published data describing HIF-1 $\alpha$ levels in muscle in diabetes (Figure 3). 


\begin{tabular}{|c|c|c|c|c|c|c|c|}
\hline & $\begin{array}{l}\text { HIF-1 } \alpha \\
\text { deletion }\end{array}$ & $\begin{array}{l}\text { Severe } \\
\text { hypoxia }\end{array}$ & $\begin{array}{l}\text { Modest } \\
\text { hypoxia }\end{array}$ & $\begin{array}{c}\mathrm{VHL} \\
\text { deletion }\end{array}$ & $\begin{array}{l}\text { PHD1 } \\
\text { deletion }\end{array}$ & $\begin{array}{c}\text { FIH } \\
\text { deletion }\end{array}$ & $\begin{array}{c}\text { Hydroxylase } \\
\text { inhibitors }\end{array}$ \\
\hline HIF-1 $\alpha$ protein & $\downarrow t \downarrow$ & $\uparrow 4 \uparrow \not \mid$ & $\uparrow \uparrow \stackrel{\partial \alpha_{1}}{\not \alpha}$ & $\uparrow \uparrow \uparrow \stackrel{\mathrm{OH}}{\mathrm{OH}}$ & $\uparrow \uparrow \uparrow \stackrel{\partial \mathrm{OH}}{\mathrm{OH}}$ & $\uparrow \uparrow \uparrow_{\partial \notin 4}^{\mathrm{OH}}$ & $\uparrow \uparrow \uparrow \stackrel{\partial k}{\not \alpha}$ \\
\hline $\begin{array}{r}\beta \text { cells } \\
\text { Function } \\
\text { Survival } \\
\text { Islet transplants }\end{array}$ & $\begin{array}{c}t \\
t \\
d\end{array}$ & $\begin{array}{l}w \downarrow \\
i \downarrow \\
i \downarrow\end{array}$ & $\stackrel{\uparrow}{\sim}$ & $\begin{array}{l}\text { wh } \\
? \\
?\end{array}$ & $\begin{array}{l}\dagger \\
? \\
?\end{array}$ & $\begin{array}{l}\text { } \\
? \\
?\end{array}$ & $\begin{array}{l}4 \\
4\end{array}$ \\
\hline $\begin{array}{r}\text { Liver } \\
\text { Glycolysis } \\
\text { Gluconeogenesis } \\
\text { Insulin sensitivity }\end{array}$ & $\begin{array}{l}\downarrow \\
\sim \\
\sim\end{array}$ & 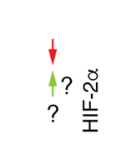 & 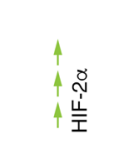 & 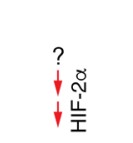 & $\begin{array}{l}? \\
? \\
?\end{array}$ & $\tilde{\sim}$ & $\stackrel{4}{\sim}$ \\
\hline $\begin{array}{r}\text { Muscle } \\
\text { Insulin sensitivity } \\
\text { Function } \\
\text { Injury/survival }\end{array}$ & $\uparrow$ (With age $\downarrow \downarrow)$ & $\begin{array}{l}w \downarrow \\
i t \\
i t\end{array}$ & $\begin{array}{l}? \\
\text { } \\
?\end{array}$ & $\begin{array}{l}? \\
? \\
?\end{array}$ & 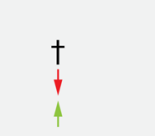 & $\begin{array}{l}\uparrow \\
\text { } \\
?\end{array}$ & $\begin{array}{l}\text { f } \\
? \\
?\end{array}$ \\
\hline $\begin{array}{r}\text { Fat } \\
\text { Insulin sensitivity } \\
\text { Obesity } \\
\text { Fibrosis }\end{array}$ & $\begin{array}{l}4 \\
\text { t }\end{array}$ & $\begin{array}{l}W \\
? \\
4\end{array}$ & $\begin{array}{l}\downarrow \\
? \\
i\end{array}$ & $\begin{array}{l}? \\
? \\
?\end{array}$ & $\begin{array}{l}\dagger \\
4 \\
?\end{array}$ & $\begin{array}{l}4 \\
\text { t } \\
?\end{array}$ & $\begin{array}{l}4 \\
? \\
?\end{array}$ \\
\hline $\begin{array}{r}\text { Complications } \\
\text { Retinopathy } \\
\text { Nephropathy } \\
\text { Neuropathy } \\
\text { Macrovascular }\end{array}$ & $\begin{array}{l}\text { t? } \\
4 \\
4\end{array}$ & 4 & 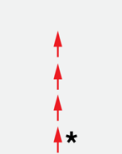 & $\begin{array}{l}4 \\
4 \\
? \\
?\end{array}$ & $\begin{array}{l}\text { Inhibitor } \\
\text { Inhibitor } \\
? \\
?\end{array}$ & $\begin{array}{l}? \\
? \\
? \\
?\end{array}$ & $\begin{array}{c}\uparrow \sim \downarrow \\
\sim \downarrow \\
? \\
i\end{array}$ \\
\hline
\end{tabular}

Figure 3. HIF-1 $\alpha$ and diabetes: effects and unknowns. Purple "OH" indicates hydroxylation of HIF-1 $\alpha$ on proline residues, and blue "OH" indicates hydroxylation on asparagine residues. In the liver, HIF-2 $\alpha$ rather than HIF-1 $\alpha$ primarily mediates some effects, as indicated. Red arrows indicate primarily deleterious effects of either increasing or decreasing hypoxia, green indicates beneficial effects, and " " indicates neutral effects. Question marks indicate unknowns and areas for potential future investigation. WWhole-body hypoxia is decreased on chow, but improved on high-fat diet. ${ }^{*}$ Note that while hypoxia is clearly a feature of macrovascular disease, hypoxic pre-exposure before the event (i.e., stroke or myocardial infarct) improves outcomes. Overall, fully hydroxylated HIF and severe hypoxia are both deleterious.

HIF-1 $\alpha$ and adipose tissue. Effects in adipose tissue suggest that the relative hypoxia seen with obesity, which is associated with increased HIF-1 $\alpha$ protein, leads to increased fibrosis in fat (60, 61). Similar increases in fibrosis are seen with overexpression of a constitutively active HIF-1 $\alpha$ (62).

In one study, decreasing HIF-1 $\alpha$ using a dominant-negative HIF-1 $\alpha$ mutant improved obesity on a high-fat diet (HFD) (63). That study reported that the HIF inhibitor PX-478 improved fat fibrosis and reduced HFD-induced weight gain. In contrast, another group found that decreasing HIF- $1 \alpha$ activity, also with a dominant-negative HIF- $1 \alpha$ mutant, increased obesity with loss of normal brown adipocyte phenotype in the interscapular brown fat pad (64). Both groups overexpressed HIF-1 $\alpha$ with deletion of the DNA-binding domain including amino acids 30-389, and the reason for the different results remains unclear. Deletion of HIF-1 $\alpha$ in adipocytes using the Cre-lox system with aP2Cre causes mice to be resistant to weight gain, to have smaller fat pads, and to display better insulin sensitivity (65).

The metabolic effects of increasing HIF-1 $\alpha$ in adipose tissue have also been examined (Figure 3). Mice with VHL deletion in adipocytes (mediated by aP2-Cre) are nonviable, dying between embryonic days 14.5 and 18.5 (66). Lethality is due to widespread hemorrhages, including in brain, liver, and skin. VHL-deficient embryos had increased expression of VEGF, which promotes blood vessel formation. Using a $\beta$-galactosidase reporter, the aP2-Cre driver has displayed strong embryonic expression in hindbrain and spine (66). This suggests that interpretation of aP2-Cre-driven mice and dominant-negative aP2-driven overexpression experiments could be complicated by its expression outside of adipose tissue.

\section{Complex effects of increasing HIF-1 $\alpha$}

Data regarding the effects of increasing HIF-1 $\alpha$ are complex and will be discussed below. Some methods of increasing HIF-1 $\alpha$ appear beneficial for $\beta$ cell function or metabolism, whereas others clearly are deleterious (67).

Acute hypoxia. Acute altitude exposure causes relative hypoxia, and acute hypoxia impairs glucose tolerance in most people. Oxygen is needed for glucose metabolism in $\beta$ cells and therefore for glucose sensing and insulin release. In people who usually reside at low altitude, spending time at high altitude, with its relative hypoxia, impairs glucose tolerance (68). Continuous glucose monitoring (CGM) assessed glucose in healthy people trekking upward and found peak glucose levels after 6 days at $3600 \mathrm{~m}$ altitude. After that, glucose homeostasis improved despite further increases in altitude (69). C-peptide, which is secreted in equimolar amounts compared to insulin, was reduced at 6 days, and then returned to levels similar to baseline. Glucose-stimulated insulin secretion was not measured.

The issue of $\beta$ cell function in hypoxic conditions is complex; people who normally live at high altitude have adaptations, and in some cases polymorphisms, and maintain normal glucose at 
altitude $(68,70,71)$. Counterintuitively, these people may show worse glucose tolerance at sea level. It is interesting to speculate that this might be because of destabilization of HIF-1 $\alpha$ with greater oxygen availability.

In cultured $\beta$ cells and islets, severe hypoxia increases stabilization of HIF- $1 \alpha$ protein, but the response is insufficient to prevent apoptosis and cell death $(72,73)$. Hypoxia downregulates the unfolded protein response independently of HIF-1 $\alpha$, and this may contribute to hypoxia-related $\beta$ cell death (74).

In contrast to very low oxygen tension (for example $1 \%$ or less), at $5 \%$ oxygen, HIF- $1 \alpha$ improves $\beta$ cell gene expression and insulin release (35). In vivo, compensation by increased respiration rate and eventually increased red blood cell formation returns overall oxygen toward normal (75). The residual smaller degree of hypoxia would be more similar to the effects of milder degrees of hypoxia and could be followed by changes in gene expression that would promote glucose uptake and metabolism.

Separate from its effects on $\beta$ cell function, altitude exposure induces insulin resistance. Men living at sea level exhibit increased insulin resistance after acute altitude increase. Insulin resistance was worst 2 days after altitude exposure but had not returned to baseline after 7 days (70). Effects of altitude on insulin resistance appear to be longer lasting than those on $\beta$ cell function. In the CGM study above, insulin resistance calculated by a homeostasis model remained worse throughout the study even though glucose improved after 6 days (69). The reverse condition was tested by the performing of clamp studies on men with chronic airway disease and hypoxia before and after oxygen supplementation. Improving their oxygenation (i.e., decreasing hypoxia) improved their insulin sensitivity (76). Similar benefits are seen in people with obstructive sleep apnea who commence therapy.

Heavy metals: cobalt and chromium. Heavy metals such as cobalt and chromium also stabilize HIF-1 $\alpha$ protein, at least partly by interfering with the interaction between HIF-1 $\alpha$ and VHL protein (32). In rats, cobalt causes deterioration in glucose tolerance, but at higher concentrations, glucose tolerance starts to improve, until toxicity is reached (77). Interestingly, chromium used to be a commonly sold nutritional supplement advertised for diabetes and lipids. However, serum chromium levels do not correlate with metabolic features in women with gestational diabetes (78), and randomized controlled trials of chromium supplementation in people with abnormal glucose tolerance show no beneficial effects on glucose homeostasis $(79,80)$, even with a documented rise in serum chromium (79). Both of these trials used chromium picolinate. A randomized controlled study of supplementation with brewer's yeast (which contains high amounts of chromium) suggested beneficial effects (81), so the effects may depend on the method of administration.

VHL protein. In mice, deletion of VHL protein worsens $\beta$ cell function in studies using either RIP-Cre or PDX1-Cre to mediate $\beta$ cell-specific deletion (82-84). Effects range from severe $\beta$ cell dysfunction (82) to normal glucose tolerance until 6 months of age and, after that, improved hemoglobin A1c (HbA1c; a routine marker of average blood glucose levels) and fasting glucose but worsened peak glucose (84). Effects of $\beta$ cell VHL deletion are ameliorated or abolished when $\beta$ cell HIF- $1 \alpha$ is also deleted.
There are surprisingly few data about diabetes in people with VHL syndrome, a condition linked to tumor formation caused by mutations in the VHL gene. One paper examining pancreatic lesions reported that 2 of 17 patients with extensive pancreatic lesions had diabetes (85). A series of 158 patients reported 3 cases of diabetes, also occurring in conjunction with pancreatic lesions (86). Five of 175 patients (2.9\%) is a low diabetes prevalence for average adult populations, but these patients were relatively young, so it remains possible that diabetes is more common with VHL syndrome than currently appreciated. A formal study testing glucose tolerance would be interesting.

An Arg200Trp mutation in VHL is responsible for some cases of Chuvash polycythemia, an autosomal recessive condition with inappropriately high erythropoietin and red blood cell numbers (87). These people have increased GLUT1 expression, and improved glucose and HbA1c levels (88). Mice engineered with the same change have substantially improved glucose tolerance tests (88). This mutation demonstrates that absence (deletion) of VHL produces effects different from those of mutations impairing its action.

Prolyl hydroxylase domain-containing proteins. As described above, prolyl hydroxylase domain-containing proteins (PHDs) function to hydroxylate HIF- $1 \alpha$ on two important prolyl residues. PHD1, also known as Egl9 family hypoxia-inducible factor 2 (EGLN2), has no identified human mutations. In mice, PHD1 deletion impairs normal oxidative muscle performance, but protects myofibers in the setting of otherwise lethal ischemia (89). On chow diet, whole-body PHD1-null mice have decreased weight with worsened insulin sensitivity and glucose tolerance (90). These mice gain more weight when eating HFD, but after 11 weeks their glucose tolerance is significantly improved, accompanied by lower serum insulin (90).

PHD2, also known as EGLN1, hydroxylates proline residues in HIF- $1 \alpha$ and HIF- $2 \alpha$. Mutations are responsible for some rare cases of familial erythrocytosis type $3(91,92)$. No cases of diabetes have been reported in individuals with this disorder. PHD2 deletion in mice is embryonic lethal in mid-gestation. Heterozygous mice are healthy and have decreased tumor spread (93) and better protection from limb ischemia (94) compared with WT mice. Small interfering RNA-mediated knockdown of PHD2 in 832/13 $\beta$ cells had no effect on glucose-stimulated insulin secretion (95). Overall, these results suggest no major role for PHD2 in glucose homeostasis.

There are no described human mutations in PHD3 (EGLN3), and its role in diabetes has not been extensively investigated. It suppresses insulin sensitivity in liver, and hepatic deletion enhanced HIF-2 $\alpha$ stability, and thereby Irs2/Akt2 signaling (96). $\beta$ Cell-specific effects of PHD3 have been reported in abstract form (97), and increased glycolysis and use of fatty acids for energy were found. On normal diet, this had no deleterious effects, but with HFD, mice developed glucose intolerance.

Asparagine hydroxylase. FIH (also called HIF-1 $\alpha$ inhibitor [HIF1AN]) hydroxylates asparagine residue 803 of HIF-1 $\alpha$ (98). This inhibits HIF-1 $\alpha$ transcriptional activity (99). FIH deletion in mice improves glucose tolerance, insulin sensitivity, and weight $(59,100)$. FIH can hydroxylate asparagine on other proteins, including members of the ankyrin family (101). It is therefore important to note that many effects of FIH deletion in murine embryonic fibroblasts are lost with codeletion of HIF-1 $\alpha$ (59). 
Iron chelation and dimethyloxalylglycine. PHDs and FIH require oxygen, iron, and 2 -oxo-glutarate ( $\alpha$-ketoglutarate) to enzymatically hydroxylate HIF on proline and asparagine residues, respectively. Decreasing iron availability increases HIF- $1 \alpha$ protein, improving $\beta$ cell function in mice fed HFD and improving wound healing when topically applied in mice $(35,102$, 103). Iron chelation also improved islet transplant outcomes by increasing HIF-1 $\alpha$ (36).

The competitive PHD inhibitor dimethyloxalylglycine (DMOG) improves wound healing on topical application (103), but it may impair functional $\beta$ cell differentiation (104). Islet transplantation has not been reported.

Overall, accumulation of hydroxylated HIF (as occurs with VHL deletion) is deleterious, and accumulation of partially hydroxylated HIF (as occurs with PHD or FIH deletion) appears beneficial.

Overexpression of constitutively active HIF-1 $\alpha$. Halberg et al. increased HIF-1 $\alpha$ in adipose tissue by expressing HIF- $1 \alpha$ without the oxygen degradation domain between amino acids 401 and 603 under control of the aP2 promoter (62). The effect was increased weight gain on chow and on HFD. HFD-fed mice had worsened glucose tolerance and increased liver lipid content. There were increased adipose tissue fibrosis and inflammation (62).

Conclusions about increasing HIF-1 $\alpha$. These different methods of increasing HIF-1 $\alpha$ have widely varying outcomes, summarized in Figure 3. Briefly: Hypoxia is deleterious because of insufficient oxygen. VHL deletion is also deleterious, suggesting that accumulation of hydroxylated HIF-1 $\alpha$ causes metabolic deterioration. The Arg200Trp mutation in VHL, however, improves glucose tolerance. Accumulation of HIF that occurs with impaired proline hydroxylation (as a result of deleting PHDs) is deleterious in PHD1-null mice, and an abstract reports that PHD3 deletion is deleterious for $\beta$ cells. In contrast, inhibiting asparagine hydroxylation improves glucose tolerance, adiposity, and muscle. Some PHD inhibitors also inhibit FIH, and these are largely beneficial.

\section{HIF-2 $\alpha$}

Unlike HIF-1 $\alpha$, HIF- $2 \alpha$ expression is confined to vertebrates (105). The HIF-2 transcription factor is composed of HIF- $2 \alpha$ and HIF-1 $\beta$. In mice, HIF- $2 \alpha$ deletion is lethal as a result of impaired placental development and fetal anomalies (106). HIF-2 $\alpha$ shares only $48 \%$ sequence homology with HIF-1 $\alpha$, but the DNA-binding sequences are more highly conserved (107). Gain-of-function mutations are associated with paraganglioma and pheochromocytoma (108-110).

There are relatively few papers reporting a role of HIF- $2 \alpha$ in diabetes. Gain-of-function changes in HIF- $2 \alpha$ are associated with better metabolic adaptation to altitude in Tibetans (71). These variants promote glycolysis and are associated with increased serum lactate. Individuals with HIF- $2 \alpha$ variants have a decreased diabetes risk at high altitude, with a seemingly paradoxical increased risk of diabetes at sea level.

Brunt et al. overexpressed HIF- $2 \alpha$ in pancreatic $\beta$ cells (111) using a PDX-Cre driver and found no change in glucose tolerance or insulin sensitivity, suggesting that HIF-2 $\alpha$ does not play a major role in $\beta$ cell function.

HIF- $2 \alpha$ does regulate hepatic insulin sensitivity (112). In liver, HIF- $2 \alpha$ regulated insulin sensitivity via insulin receptor substrate
2 (Irs2) and suppressed gluconeogenesis. In partnership with this effect, HIF-2 $\alpha$ also inhibits glucagon stimulation of gluconeogenesis after feeding (113). In contrast, HIF-1 $\alpha$ regulated only hepatic glycolysis, similar to its effects in $\beta$ cells (112).

A recent paper reported an age-related decline in hypothalamic HIF-2 $\alpha$ levels that was associated with worsened weight gain, adiposity, and insulin sensitivity in response to HFD (114). The same paper reported that proopiomelanocortin (POMC) neuron-specific deletion of HIF- $2 \alpha$ increased fat mass and age-related weight gain with mild impairment of glucose tolerance and increased insulin resistance.

\section{HIFs and microvascular complications of diabetes}

In addition to roles in the pathogenesis of $\beta$ cell dysfunction, insulin resistance, and obesity, HIFs play roles in the complications of diabetes. The microvascular complications of diabetes (retinopathy, nephropathy, and neuropathy) occur in tissues with constitutively active glucose transporters that lack substantial insulin-mediated glucose uptake. Given the ability of hyperglycemia to downregulate HIF protein, as discussed above, the role of HIF in these complications is of interest.

HIFs and retinopathy. The retina experiences relative hypoxia at high glucose levels due to glucose-induced destabilization of HIF-1 $\alpha$. Intensive diabetes therapy and the consequent improvement in glucose levels increase HIF- $1 \alpha$, which in turn facilitates new blood vessel growth and short-term retinopathy progression in experimental models (115) and in humans (116). It is important to note that despite increased short-term disease progression, people with more intensive glucose control have better long-term eye outcomes.

Cross-sectional data suggest that glucose variability, which would be predicted to cause fluctuations in HIF- $1 \alpha$ protein, is associated with increased retinopathy (117). Higher day-to-day variation in fasting glucose prospectively predicts risk of retinopathy $(118,119)$. However, not all studies find significant associations (120). Perhaps because CGM is a relatively recently developed technology, prospective long-term data are not yet available. Overall, a role for HIF and glucose variability is plausible; experimental intermittent hypoxia causes more HIF-1 $\alpha$ fluctuation than continuous hypoxia of the same severity (121). Clinically, obstructive sleep apnea causes intermittent hypoxia and is associated with increased retinopathy (122), and people with sleep apnea who use their therapeutic masks more often have decreased retinopathy (123). However, compliance with sleep apnea therapy may correspond with compliance with other therapies, so this does not demonstrate causality.

HIF- $1 \alpha$ is involved in the pathogenesis of retinopathy in the animal model of hyperoxia-normoxia in neonatal rodents (124). In humans, retinopathy occurs in premature newborns who are treated with high oxygen concentrations (retinopathy of prematurity).

Ocular HIF-1 $\alpha$ protein and its transcriptional target VEGF are increased in diabetic retinopathy (125). Neutralizing antibodies directed against VEGF have markedly improved outcomes for proliferative diabetic retinopathy and for "wet" macular edema $(126,127)$, showing that this pathway is clinically important in human retinopathy. 
PHD inhibition decreases retinopathy in a rat model (128). Increasing HIF- $1 \alpha$ in the eye by inhibiting PHDs with DMOG prevents oxygen-induced retinopathy (129). The HIF-1 $\alpha$ Pro582Ser polymorphism confers resistance to hyperglycemia-mediated decreases in HIF-1 $\alpha$ protein. This polymorphism associates with decreased risk of retinopathy (130). Overall, some methods of increasing HIF- $1 \alpha$ are beneficial for retinopathy progression, and this indicates an area with scope for further research, especially related to conditions with relatively less vascular retinal disease, e.g., "dry" macular edema, or already lasered retinas.

Nephropathy, diabetes, and HIFs. In many countries, diabetes is the most common cause of end-stage renal failure. Renal tubular fibrosis is an important contributor. Relative intrarenal hypoxia is present $(131,132)$, and increased HIF-1 $\alpha$ in kidneys associates with increased renal fibrosis $(131,133)$. The relationship between HIF and renal fibrosis is reviewed in ref. 134. Cellular communication network factor 2 (CCN2; also called connective tissue growth factor [CTGF]) is a profibrogenic agent involved in nephropathy pathogenesis (135). In hypoxia, CCN2 expression is directly regulated by HIF-1 $\alpha$ (136).

SGLT2 inhibitors are a relatively new class of diabetes drug with major renoprotective effects in diabetes (137). Empagliflozin and dapagliflozin are both renoprotective in animal models, and both decrease renal HIF-1 $\alpha(138,139)$. Since inhibiting HIF-1 $\alpha$ ablated the protection (139), it is possible that the HIF-1 $\alpha$ decrease is indirect, via diminishing relative hypoxia.

Overexpression of HIF- $1 \alpha$ by deletion of renal VHL causes adverse renal outcomes (140). However, increasing HIF-1 $\alpha$ with cobalt chloride improves renal outcomes in diabetes models (141, 142). The Pro582Ser polymorphism in HIF-1 $\alpha$ that is associated with decreased retinopathy (130) is also associated with decreased nephropathy in human diabetes (143). These results suggest that analogous to the situation in $\beta$ cells, the method of increasing HIF$1 \alpha$ controls renal outcomes. Heterozygous HIF-1 $\alpha$ deletion exacerbates renal ischemia/reperfusion injury, and in WT mice stimulators of HIF stabilization improve outcomes (144).

Neuropathy and HIFs. Peripheral neuropathy in diabetes is associated with changes in the small blood vessels supplying nerves. Hyperglycemia increases energy availability, which may induce mitochondrial dysfunction and increase reactive oxygen species. While there is transient HIF-1 $\alpha$ induction following experimental diabetes onset (145), mice with peripheral nerve-specific HIF-1 $\alpha$ deletion develop more severe nerve damage (146), consistent with a protective role for HIF- $1 \alpha$.

Other than pain, the major consequence of peripheral neuropathy is risk of foot ulcers. Diabetes is the most common cause of preventable nontraumatic lower-limb amputations, causing more than 100,000 amputations yearly in the United States (147). There are several studies linking HIF to poor wound healing in diabetes $(102,148,149)$, and HIF- $1 \alpha$ is decreased in chronic foot ulcers (44). In diabetes, hyperbaric oxygen (which increases oxygen availability) paradoxically increases HIF-1 $\alpha$ protein (148) and improves healing. Increasing HIF- $1 \alpha$ with topical iron chelators stimulated experimental wound healing in mice. The benefit was lost with myeloid cell-specific HIF-1 $\alpha$ deletion (102).

Macrovascular complications of diabetes. Cardiovascular diseases are the most common cause of death in people with diabetes (150-152). Increased atherosclerosis, hypertension, and dyslip- idemia all play roles. People with diabetes have worse outcomes after cardiac events, with poorer collateral vessel development, larger infarcts, and increased risk of heart failure (153). A number of hypoglycemic agents may decrease cardiac risk in T2D $(154,155)$. Each hypoglycemic agent decreases blood glucose, consistent with their original therapeutic intent, but the decrease in adverse cardiovascular events is not proportional to changes in HbA1c, indicating that non-glucose effects are important. For example, canagliflozin and empagliflozin decrease death by more than $30 \%$ within the study period but only decrease HbA1c by $0.5 \%-0.9 \%$. Other agents with larger effects on glucose, such as semaglutide, are also beneficial, but have similar or smaller magnitude of effect on cardiac outcomes despite HbA1c benefits of greater than $1.5 \%$. The effects of these agents on HIF-1 $\alpha$ protein has not been reported.

HIF is important for normal remodeling in the cardiovascular system, as reviewed in ref. 156. Cardiac-specific HIF-1 $\alpha$ deletion causes worsened cardiac function in nondiabetic animals (157). Cardiac-specific deletion of HIF- $1 \beta$ in nondiabetic mice leads to cardiomyopathy with impaired cardiac lipid metabolism (158). Heterozygous whole-body deletion of HIF- $1 \alpha$ increases risk of impaired cardiac function after diabetes induction (159).

Cardiac overexpression of HIF-1 $\alpha$ improves cardiac function and outcomes in a rodent diabetes model (160). Patients with VHL syndrome, who have increased HIF-1 $\alpha$, appear to have reduced cardiovascular death, although this may be confounded by an increase in premature death from cerebral hemangioblastomas and malignancies (161).

\section{Summary and conclusions}

HIFs play a role in the pathogenesis of $\beta$ cell dysfunction and diabetes. Hyperglycemia destabilizes HIF-1 $\alpha$ protein, causing impaired hypoxia responses. HIF- $1 \alpha$ plays a role in obesity and the ability of adipose tissue to compensate for increased mass without excess fibrosis and inflammation.

The complications of diabetes - both the macrovascular and the microvascular ones - involve dysregulation of HIF- $1 \alpha$. Decreased HIF-1 $\alpha$ activity is associated with most complications. However, for proliferative retinopathy, inhibition of VEGF action benefits vision outcomes by decreasing bleeding neovasculature and retinal detachment. Deletion of HIF- $1 \alpha$ worsens most diabetes complications, as well as $\beta$ cell function itself.

Given the adverse effects of decreased HIF- $1 \alpha$, it seems logical to consider whether increasing it is beneficial. So it is noteworthy that increasing HIF- $1 \alpha$ by decreasing VHL has adverse consequences in most tissues. In contrast, increasing HIF- $1 \alpha$ by decreasing or deleting FIH or the prolyl hydroxylases may have beneficial effects.

Severe hypoxia is harmful and cannot be fully compensated for by HIFs and their downstream effects. Accumulation of fully hydroxylated HIF-1 $\alpha$, as seen with VHL deletion, is also harmful. In contrast, accumulation of partially hydroxylated or unhydroxylated HIFs seen with modest hypoxia, PHD deletion, FIH deletion, or PHD/FIH inhibition has some beneficial effects. Gene expression studies suggest that different effects are observed with VHL deficiency, indicating that fully hydroxylated HIFs have quite different actions. Possibly, understanding these effects may help with treating VHL syndrome. 
Areas of HIF biology remain that are not yet described or are complicated by studies with conflicting results (Figure 3). Because of the complex regulation involved in HIF pathways and across various tissues, further research is needed to understand whether any strategies for increasing HIF-1 $\alpha$ protein may be used to decrease diabetes development or reduce risk of diabetes complications.

\section{Acknowledgments}

JEG receives National Health and Medical Research Council grant support from the program grant Nutrition and Complexity 1149976.

Address correspondence to: Jenny E. Gunton, Edward Ford Building (A27) Fisher Road, University of Sydney, NSW 2006, Australia.Email: Jenny.Gunton@sydney.edu.au.
1. Cho NH, et al. IDF Diabetes Atlas: global estimates of diabetes prevalence for 2017 and projections for 2045. Diabetes Res Clin Pract. 2018;138:271-281.

2. Gregg EW, Sattar N, Ali MK. The changing face of diabetes complications. Lancet Diabetes Endocrinol. 2016;4(6):537-547.

3. Roglic G, Unwin N. Mortality attributable to diabetes: estimates for the year 2010. Diabetes Res Clin Pract. 2010;87(1):15-19.

4. Thong FS, Dugani CB, Klip A. Turning signals on and off: GLUT4 traffic in the insulin-signaling highway. Physiology (Bethesda). 2005;20:271-284.

5. Huang S, Czech MP. The GLUT4 glucose transporter. Cell Metab. 2007;5(4):237-252.

6. Klip A, McGraw TE, James DE. Thirty sweet years of GLUT4. J Biol Chem. 2019;294(30):11369-11381.

7. Knip M, Siljander H. Autoimmune mechanisms in type 1 diabetes. Autoimmun Rev. 2008;7(7):550-557.

8. Bach JF. Insulin-dependent diabetes mellitus as an autoimmune disease. Endocr Rev. 1994;15(4):516-542.

9. Fourlanos S, Narendran P, Byrnes G, Colman $\mathrm{P}$, Harrison L. Insulin resistance is a risk factor for progression to type 1 diabetes. Diabetologia. 2004;47(10):1661-1667.

10. Kahn SE, Hull RL, Utzschneider KM. Mechanisms linking obesity to insulin resistance and type 2 diabetes. Nature. 2006;444(7121):840-846.

11. Seidell JC. Obesity, insulin resistance and diabetes-a worldwide epidemic. Br J Nutr. 2000;83(suppl 1):S5-S8.

12. Kasuga M. Insulin resistance and pancreatic beta cell failure. J Clin Invest. 2006;116(7):1756-1760.

13. Kewley RJ, Whitelaw ML, Chapman-Smith A. The mammalian basic helix-loop-helix/PAS family of transcriptional regulators. Int J Biochem Cell Biol. 2004;36(2):189-204.

14. Bracken CP, Whitelaw ML, Peet DJ. The hypoxia-inducible factors: key transcriptional regulators of hypoxic responses. Cell Mol Life Sci. 2003;60(7):1376-1393.

15. Wang GL, Jiang BH, Rue EA, Semenza GL. Hypoxia-inducible factor 1 is a basic-helixloop-helix-PAS heterodimer regulated by cellular O2 tension. Proc Natl Acad Sci U S A. 1995;92(12):5510-5514.

16. Wang GL, Semenza GL. General involvement of hypoxia-inducible factor 1 in transcriptional response to hypoxia. Proc Natl Acad Sci US A. 1993;90(9):4304-4308.

17. Semenza GL, Wang GL. A nuclear factor induced by hypoxia via de novo protein synthesis binds to the human erythropoietin gene enhancer at a site required for transcriptional activation. Mol Cell Biol. 1992;12(12):5447-5454.

18. Lowell BB, Shulman GI. Mitochondrial dysfunction and type 2 diabetes. Science. 2005;307(5708):384-387.

19. Ryan HE, Lo J, Johnson RS. HIF-1 alpha is required for solid tumor formation and embryonic vascularization. EMBO J.1998;17(11):3005-3015.

20. Ramirez JM, Severs LJ, Ramirez SC, Agosto-Marlin IM. Advances in cellular and integrative control of oxygen homeostasis within the central nervous system. J Physiol. 2018;596(15):3043-3065.

21. Semenza GL, Shimoda LA, Prabhakar NR. Regulation of gene expression by HIF-1. Novartis Found Symp. 2006;272:2-8; discussion 8.

22. Ruas JL, Poellinger L. Hypoxia-dependent activation of HIF into a transcriptional regulator. Semin Cell Dev Biol. 2005;16(4-5):514-522.

23. Schofield CJ, Ratcliffe PJ. Oxygen sensing by HIF hydroxylases. Nat Rev Mol Cell Biol. 2004;5(5):343-354.

24. Triantafyllou A, Liakos P, Tsakalof A, Georgatsou E, Simos G, Bonanou S. Cobalt induces hypoxia-inducible factor-1alpha (HIF-1alpha) in HeLa cells by an iron-independent, but ROS-, PI-3Kand MAPK-dependent mechanism. Free Radic Res. 2006;40(8):847-856.

25. Bilton RL, Booker GW. The subtle side to hypoxia inducible factor (HIFalpha) regulation. Eur J Biochem. 2003;270(5):791-798.

26. Zagorska A, Dulak J. HIF-1: the knowns and unknowns of hypoxia sensing. Acta Biochim Pol. 2004;51(3):563-585.

27. Jaakkola P, et al. Targeting of HIF-alpha to the von Hippel-Lindau ubiquitylation complex by O2-regulated prolyl hydroxylation. Science. 2001;292(5516):468-472.

28. Bruick RK, McKnight SL. A conserved family of prolyl-4-hydroxylases that modify HIF. Science. 2001;294(5545):1337-1340.

29. Kamura T, Sato S, Iwai K, Czyzyk-Krzeska M, Conaway RC, Conaway JW. Activation of HIF1alpha ubiquitination by a reconstituted von Hippel-Lindau (VHL) tumor suppressor complex. Proc Natl Acad Sci U S A. 2000;97(19):10430-10435.

30. Huang LE, Arany Z, Livingston DM, Bunn HF. Activation of hypoxia-inducible transcription factor depends primarily upon redox-sensitive stabilization of its alpha subunit. J Biol Chem. 1996;271(50):32253-32259.

31. Wang GL, Semenza GL. Desferrioxamine induces erythropoietin gene expression and hypoxia-inducible factor 1 DNA-binding activity: implications for models of hypoxia signal transduction. Blood. 1993;82(12):3610-3615.

32. Yuan Y, Hilliard G, Ferguson T, Millhorn DE. Cobalt inhibits the interaction between hypoxia-inducible factor-alpha and von Hippel-Lindau protein by direct binding to hypoxia-inducible factor-alpha. J Biol Chem. 2003;278(18):15911-15916. 33. Gunton JE, et al. Loss of ARNT/HIF1beta medi- ates altered gene expression and pancreatic-islet dysfunction in human type 2 diabetes. Cell. 2005;122(3):337-349.

34. Levisetti MG, Polonsky KS. Diabetic pancreatic beta cells ARNT all they should be. Cell Metab. 2005;2(2):78-80.

35. Cheng K, et al. Hypoxia-inducible factor-1alpha regulates beta cell function in mouse and human islets. J Clin Invest. 2010;120(6):2171-2183.

36. Stokes RA, et al. Hypoxia-inducible factor- $1 \alpha$ (HIF-1 $\alpha$ ) potentiates $\beta$-cell survival after islet transplantation of human and mouse islets. Cell Transplant. 2013;22(2):253-266.

37. Cheng K, Andrikopoulos S, Gunton JE. First phase insulin secretion and type 2 diabetes. Curr Mol Med. 2013;13(1):126-139.

38. Davies MJ, Rayman G, Grenfell A, Gray IP, Day JL, Hales CN. Loss of the first phase insulin response to intravenous glucose in subjects with persistent impaired glucose tolerance. Diabet Med.1994;11(5):432-436.

39. Weir GC, Bonner-Weir S. Five stages of evolving beta-cell dysfunction during progression to diabetes. Diabetes. 2004;53(suppl 3):S16-S21.

40. Colman PG, et al. The Melbourne Pre-Diabetes Study: prediction of type 1 diabetes mellitus using antibody and metabolic testing. Med J Aust. 1998;169(2):81-84.

41. Lalwani A, et al. $\beta$ Cell hypoxia-inducible factor- $1 \alpha$ is required for the prevention of type 1 diabetes. Cell Rep. 2019;27(8):2370-2384.

42. Hewitson KS, et al. Structural and mechanistic studies on the inhibition of the hypoxia-inducible transcription factor hydroxylases by tricarboxylic acid cycle intermediates. J Biol Chem. 2007;282(5):3293-3301.

43. Weidemann A, Johnson RS. Biology of HIF-1alpha. Cell Death Differ. 2008;15(4):621-627.

44. Catrina SB, Okamoto K, Pereira T, Brismar K, Poellinger L. Hyperglycemia regulates hypoxiainducible factor-1alpha protein stability and function. Diabetes. 2004;53(12):3226-3232.

45. Bento CF, Pereira P. Regulation of hypoxia-inducible factor 1 and the loss of the cellular response to hypoxia in diabetes. Diabetologia. 2011;54(8):1946-1956.

46. Dodd MS, et al. Fatty acids prevent hypoxia-inducible factor-1 $\alpha$ signaling through decreased succinate in diabetes. JACC Basic Transl Sci. 2018;3(4):485-498.

47. Pessin JE, Saltiel AR. Signaling pathways in insulin action: molecular targets of insulin resistance. JClin Invest. 2000;106(2):165-169.

48. Sell H, Dietze-Schroeder D, Eckel J. The adipocyte-myocyte axis in insulin resistance. Trends Endocrinol Metab. 2006;17(10):416-422.

49. Gorgens SW, et al. Hypoxia in combination with muscle contraction improves insulin 
action and glucose metabolism in human skeletal muscle via the HIF-1 $\alpha$ pathway. Diabetes. 2017;66(11):2800-2807.

50. Lindholm ME, Rundqvist H. Skeletal muscle hypoxia-inducible factor-1 and exercise. Exp Physiol. 2016;101(1):28-32.

51. Favier FB, Britto FA, Freyssenet DG, Bigard XA, Benoit H. HIF-1-driven skeletal muscle adaptations to chronic hypoxia: molecular insights into muscle physiology. Cell Mol Life Sci. 2015;72(24):4681-4696.

52. Badin PM, Sopariwala DH, Lorca S, Narkar VA. Muscle Arnt/Hif1 $\beta$ is dispensable in myofiber type determination, vascularization and insulin sensitivity. PLoS One. 2016;11(12):e0168457.

53. Sakagami H, et al. Loss of HIF-1 $\alpha$ impairs GLUT4 translocation and glucose uptake by the skeletal muscle cells. Am J Physiol Endocrinol Metab. 2014;306(9):E1065-E1076.

54. Mason SD, et al. Loss of skeletal muscle HIF-1alpha results in altered exercise endurance. PLOS Biol. 2004;2(10):e288.

55. Sinha KM, et al. Hypoxia-inducible factor $1 \alpha$ (HIF-1 $\alpha$ ) is a major determinant in the enhanced function of muscle-derived progenitors from MRL/MpJ mice. FASEB J. 2019;33(7):8321-8334.

56. Billin AN, et al. HIF prolyl hydroxylase inhibition protects skeletal muscle from eccentric contraction-induced injury. Skelet Muscle. 2018;8(1):35.

57. Sinha I, et al. Prolyl hydroxylase domain-2 inhibition improves skeletal muscle regeneration in a male murine model of obesity. Front Endocrinol (Lausanne). 2017;8:153.

58. Döring F, et al. A common haplotype and the Pro582Ser polymorphism of the hypoxia-inducible factor-1alpha (HIF1A) gene in elite endurance athletes. J Appl Physiol (1985). 2010;108(6):1497-1500.

59. Sim J, et al. The factor inhibiting HIF asparaginyl hydroxylase regulates oxidative metabolism and accelerates metabolic adaptation to hypoxia. Cell Metab. 2018;27(4):898-913.e7.

60. Sun K, Tordjman J, Clément K, Scherer PE. Fibrosis and adipose tissue dysfunction. Cell Metab. 2013;18(4):470-477.

61. Guglielmi V, et al. Omental adipose tissue fibrosis and insulin resistance in severe obesity. Nutr Diabetes. 2015;5:e175.

62. Halberg N, et al. Hypoxia-inducible factor 1alpha induces fibrosis and insulin resistance in white adipose tissue. Mol Cell Biol. 2009;29(16):4467-4483.

63. Sun K, Halberg N, Khan M, Magalang UJ, Scherer PE. Selective inhibition of hypoxia-inducible factor $1 \alpha$ ameliorates adipose tissue dysfunction. Mol Cell Biol. 2013;33(5):904-917.

64. Zhang X, et al. Adipose tissue-specific inhibition of hypoxia-inducible factor $1 \alpha$ induces obesity and glucose intolerance by impeding energy expenditure in mice. J Biol Chem. 2010;285(43):32869-32877.

65. Jiang C, et al. Disruption of hypoxia-inducible factor 1 in adipocytes improves insulin sensitivity and decreases adiposity in high-fat diet-fed mice. Diabetes. 2011;60(10):2484-2495.

66. Zhang J, Wang Y, Gao Z, Yun Z, Ye J. Hypoxiainducible factor 1 activation from adipose protein 2-cre mediated knockout of von Hippel-Lindau gene leads to embryonic lethality. Clin Exp Phar- macol Physiol. 2012;39(2):145-150.

67. Gonzalez FJ, Xie C, Jiang C. The role of hypoxia-inducible factors in metabolic diseases. Nat Rev Endocrinol. 2018;15(1):21-32.

68. Srivastava KK, Kumria MM, Grover SK, Sridharan K, Malhotra MS. Glucose tolerance of lowlanders during prolonged stay at high altitude and among high altitude natives. Aviat Space Environ Med. 1975;46(2):144-146.

69. Hill NE, et al. Continuous glucose monitoring at high altitude-effects on glucose homeostasis. Med Sci Sports Exerc. 2018;50(8):1679-1686.

70. Larsen JJ, Hansen JM, Olsen NV, Galbo H, Dela F. The effect of altitude hypoxia on glucose homeostasis in men. J Physiol. 1997;504(1):241-249.

71. Ge RL, Simonson TS, Gordeuk V, Prchal JT, McClain DA. Metabolic aspects of highaltitude adaptation in Tibetans. Exp Physiol. 2015;100(11):1247-1255.

72. Miao G, et al. Dynamic production of hypoxia-inducible factor-1alpha in early transplanted islets. Am J Transplant. 2006;6(11):2636-2643.

73. Moritz W, et al. Apoptosis in hypoxic human pancreatic islets correlates with HIF-1alpha expression. FASEB J. 2002;16(7):745-747.

74. Bensellam M, et al. Hypoxia reduces ER-to-Golgi protein trafficking and increases cell death by inhibiting the adaptive unfolded protein response in mouse beta cells. Diabetologia. 2016;59(7):1492-1502.

75. Bensellam M, et al. Glucose-induced $\mathrm{O}_{2}$ consumption activates hypoxia inducible factors 1 and 2 in rat insulin-secreting pancreatic betacells. PLoS One. 2012;7(1):e29807.

76. Jakobsson P, Jorfeldt L. Oxygen supplementation increases glucose tolerance during euglycaemic hyperinsulinaemic glucose clamp procedure in patients with severe COPD and chronic hypoxaemia. Clin Physiol Funct Imaging. 2006;26(5):271-274.

77. Roginski EE, Mertz W. A biphasic response of rats to cobalt. J Nutr. 1977;107(8):1537-1542.

78. Gunton JE, Hams G, Hitchman R, McElduff A. Serum chromium does not predict glucose tolerance in late pregnancy. Am J Clin Nutr. 2001;73(1):99-104

79. Gunton JE, et al. Chromium supplementation does not improve glucose tolerance, insulin sensitivity, or lipid profile: a randomized, placebo-controlled, double-blind trial of supplementation in subjects with impaired glucose tolerance. Diabetes Care. 2005;28(3):712-713.

80. Ali A, Ma Y, Reynolds J, John Wise S, Inzucchi S, Katz D. Chromium effects on glucose tolerance and insulin sensitivity in persons at risk for diabetes mellitus. Endocr Pract. 2011;17(1):16-25.

81. Sharma S, Agrawal RP, Choudhary M, Jain S, Goyal S, Agarwal V. Beneficial effect of chromium supplementation on glucose, $\mathrm{HbA1C}$ and lipid variables in individuals with newly onset type-2 diabetes. J Trace Elem Med Biol. 2011;25(3):149-153.

82. Cantley J, et al. Deletion of the von Hippel-Lindau gene in pancreatic beta cells impairs glucose homeostasis in mice. JClin Invest. 2009;119(1):125-135.

83. Puri S, Cano DA, Hebrok M. A role for von Hippel-Lindau protein in pancreatic beta-cell func- tion. Diabetes. 2009;58(2):433-441.

84. Zehetner J, et al. PVHL is a regulator of glucose metabolism and insulin secretion in pancreatic beta cells. Genes Dev. 2008;22(22):3135-3146.

85. Mukhopadhyay B, Sahdev A, Monson JP, Besser GM, Reznek RH, Chew SL. Pancreatic lesions in von Hippel-Lindau disease. Clin Endocrinol (Oxf). 2002;57(5):603-608.

86. Hammel PR, et al. Pancreatic involvement in von Hippel-Lindau disease. The Groupe Francophone d'Etude de la Maladie de von Hippel-Lindau. Gastroenterology. 2000;119(4):1087-1095.

87. Ang SO, et al. Disruption of oxygen homeostasis underlies congenital Chuvash polycythemia. Nat Genet. 2002;32(4):614-621.

88. McClain DA, et al. Decreased serum glucose and glycosylated hemoglobin levels in patients with Chuvash polycythemia: a role for HIF in glucose metabolism. J Mol Med (Berl). 2013;91(1):59-67.

89. Aragonés J, et al. Deficiency or inhibition of oxygen sensor Phd1 induces hypoxia tolerance by reprogramming basal metabolism. Nat Genet. 2008;40(2):170-180.

90. Thomas A, et al. Hypoxia-inducible factor prolyl hydroxylase 1 (PHD1) deficiency promotes hepatic steatosis and liver-specific insulin resistance in mice. Sci Rep. 2016;6:24618.

91. Percy MJ, et al. A family with erythrocytosis establishes a role for prolyl hydroxylase domain protein 2 in oxygen homeostasis. Proc Natl Acad Sci U S A. 2006;103(3):654-659.

92. Percy MJ, et al. Chuvash-type congenital polycythemia in 4 families of Asian and Western European ancestry. Blood. 2003;102(3):1097-1099.

93. Mazzone M, et al. Heterozygous deficiency of PHD2 restores tumor oxygenation and inhibits metastasis via endothelial normalization. Cell. 2009;136(5):839-851.

94. Takeda Y, et al. Macrophage skewing by Phd2 haplodeficiency prevents ischaemia by inducing arteriogenesis. Nature. 2011;479(7371):122-126.

95. Huang M, Paglialunga S, Wong JM, Hoang M, Pillai R, Joseph JW. Role of prolyl hydroxylase domain proteins in the regulation of insulin secretion. Physiol Rep. 2016;4(5):e12722.

96. Taniguchi CM, et al. Cross-talk between hypoxia and insulin signaling through $\mathrm{Phd} 3$ regulates hepatic glucose and lipid metabolism and ameliorates diabetes. Nat Med. 2013;19(10):1325-1330.

97. Cuozzo F, et al. Prolyl-hydroxylase 3 maintains [beta]-cell glucose-sensing under metabolic stress. Paper presented at: Society for Endocrinology BES 2019; November 11-13, 2019; Brighton, United Kingdom. https://www.endocrine-abstracts.org/ea/0065/ea0065oc1.5. Accessed August 3, 2020.

98. Lando D, Peet DJ, Whelan DA, Gorman JJ, Whitelaw ML. Asparagine hydroxylation of the HIF transactivation domain a hypoxic switch. Science. 2002;295(5556):858-861.

99. Mahon PC, Hirota K, Semenza GL. FIH-1: a novel protein that interacts with HIF-1alpha and VHL to mediate repression of HIF-1 transcriptional activity. Genes Dev. 2001;15(20):2675-2686

100.Zhang N, et al. The asparaginyl hydroxylase factor inhibiting HIF-1alpha is an essential regulator of metabolism. Cell Metab. 2010;11(5):364-378.

101. Yang M, et al. Asparagine and aspartate hydrox- 
ylation of the cytoskeletal ankyrin family is catalyzed by factor-inhibiting hypoxia-inducible factor. J Biol Chem. 2011;286(9):7648-7660.

102. Scott C, et al. Reduction of ARNT in myeloid cells causes immune suppression and delayed wound healing. Am J Physiol Cell Physiol. 2014;307(4):C349-C357.

103. Duscher D, et al. Comparison of the hydroxylase inhibitor dimethyloxalylglycine and the iron chelator deferoxamine in diabetic and aged wound healing. Plast Reconstr Surg. 2017;139(3):695e-706e.

104. Heinis M, et al. Oxygen tension regulates pancreatic beta-cell differentiation through hypoxia-inducible factor 1alpha. Diabetes. 2010;59(3):662-669.

105. Semenza GL. Hypoxia-inducible factors in physiology and medicine. Cell. 2012;148(3):399-408.

106. Cowden Dahl KD, et al. Hypoxia-inducible factors 1alpha and 2alpha regulate trophoblast differentiation. Mol Cell Biol. 2005;25(23):10479-10491.

107. Tian H, McKnight SL, Russell DW. Endothelial PAS domain protein 1 (EPAS1), a transcription factor selectively expressed in endothelial cells. Genes Dev. 1997;11(1):72-82.

108.Zhuang Z, et al. Somatic HIF2A gain-of-function mutations in paraganglioma with polycythemia. NEngl JMed. 2012;367(10):922-930.

109. Favier J, Buffet A, Gimenez-Roqueplo AP. HIF2A mutations in paraganglioma with polycythemia. NEngl J Med.2012;367(22):2161.

110. Rosenblum JS, et al. Chiari malformation type 1 in EPAS1-associated syndrome. Int J Mol Sci. 2019;20(11):2819.

111. Brunt JJ, Shi SY, Schroer SA, Sivasubramaniyam T, Cai EP, Woo M. Overexpression of HIF-2 $\alpha$ in pancreatic $\beta$ cells does not alter glucose homeostasis. Islets. 2014;6(5-6):e1006075.

112. Wei K, et al. A liver Hif-2 $\alpha$-Irs2 pathway sensitizes hepatic insulin signaling and is modulated by Vegf inhibition. Nat Med. 2013;19(10):1331-1337.

113. Ramakrishnan Sadeesh $\mathrm{K}$, et al. HIF $2 \alpha$ is an essential molecular brake for postprandial hepatic glucagon response independent of insulin signaling. Cell Metab. 2016;23(3):505-516.

114. Wang Z, Khor S, Cai D. Age-dependent decline of hypothalamic HIF $2 \alpha$ in response to insulin and its contribution to advanced age-associated metabolic disorders in mice. J Biol Chem. 2019;294(13):4946-4955.

115. Poulaki V, et al. Acute intensive insulin therapy exacerbates diabetic blood-retinal barrier breakdown via hypoxia-inducible factor-1alpha and VEGF. J Clin Invest. 2002;109(6):805-815.

116. Diabetes Control Complications Trial Research Group, et al. The effect of intensive treatment of diabetes on the development and progression of long-term complications in insulin-dependent diabetes mellitus. $N$ Engl JMed. 1993;329(14):977-986.

117. Sartore G, Chilelli NC, Burlina S, Lapolla AJAD. Association between glucose variability as assessed by continuous glucose monitoring (CGM) and diabetic retinopathy in type 1 and type 2 diabetes. Acta Diabetol. 2013;50(3):437-442.

118. Takao T, Inoue K, Suka M, Yanagisawa H, Iwamoto Y. Optimal cutoff values of fasting plasma glucose (FPG) variability for detecting retinopathy and the threshold of FPG levels for predicting the risk of retinopathy in type 2 diabetes: a longitudinal study over 27 years. Diabetes Res Clin Pract. 2018;140:228-235.

119. Zhao Q, Zhou F, Zhang Y, Zhou X, Ying C. Fasting plasma glucose variability levels and risk of adverse outcomes among patients with type 2 diabetes: a systematic review and meta-analysis. Diabetes Res Clin Pract. 2019;148:23-31.

120. Kilpatrick ES, Rigby AS, Atkin SL. The effect of glucose variability on the risk of microvascular complications in type 1 diabetes. Diabetes Care. 2006;29(7):1486-1490.

121. Yuan G, Nanduri J, Bhasker CR, Semenza GL, Prabhakar NR. Ca2+/calmodulin kinase-dependent activation of hypoxia inducible factor 1 transcriptional activity in cells subjected to intermittent hypoxia. J Biol Chem. 2005;280(6):4321-4328.

122. Chew M, Tan NYQ, Lamoureux E, Cheng CY, Wong TY, Sabanayagam C. The associations of objectively measured sleep duration and sleep disturbances with diabetic retinopathy. Diabetes Res Clin Pract. 2019;159:107967.

123. Smith JP, Cyr LG, Dowd LK, Duchin KS, Lenihan PA, Sprague J. The Veterans Affairs Continuous Positive Airway Pressure Use and Diabetic Retinopathy Study. Optom Vis Sci. 2019;96(11):874-878.

124. Smith LE, et al. Oxygen-induced retinopathy in the mouse. Invest Ophthalmol Vis Sci. 1994;35(1):101-111.

125. Wang $X$, Wang $G$, Wang $Y$. Intravitreous vascular endothelial growth factor and hypoxia-inducible factor 1a in patients with proliferative diabetic retinopathy. Am JOphthalmol. 2009;148(6):883-889.

126. Avery RL, et al. Intravitreal bevacizumab (Avastin) in the treatment of proliferative diabetic retinopathy. Ophthalmology. 2006;113(10):1695-1705.

127. Arevalo JF, et al. Primary intravitreal bevacizum$\mathrm{ab}$ (Avastin) for diabetic macular edema: results from the Pan-American Collaborative Retina Study Group at 6-month follow-up. Ophthalmology. 2007;114(4):743-750.

128. Trichonas G, Lee TJ, Hoppe G, Au J, Sears JE. Prolyl hydroxylase inhibition during hyperoxia prevents oxygen-induced retinopathy in the rat 50/10 model. Invest Ophthalmol Vis Sci. 2013;54(7):4919-4926.

129. Sears JE, Hoppe G, Ebrahem Q, Anand-Apte B. Prolyl hydroxylase inhibition during hyperoxia prevents oxygen-induced retinopathy. Proc Natl Acad Sci U S A. 2008;105(50):19898-19903.

130. Ekberg NR, et al. Protective effect of the HIF-1A Pro582Ser polymorphism on severe diabetic retinopathy. J Diabetes Res. 2019;2019:2936962.

131. Nangaku M. Chronic hypoxia and tubulointerstitial injury: a final common pathway to end-stage renal failure. J Am Soc Nephrol. 2006;17(1):17-25.

132. Ries M, et al. Renal diffusion and BOLD MRI in experimental diabetic nephropathy. Blood oxygen level-dependent. J Magn Reson Imaging. 2003;17(1):104-113.

133. Higgins DF, et al. Hypoxia promotes fibrogenesis in vivo via HIF-1 stimulation of epithelial-to-mesenchymal transition. J Clin Invest. 2007;117(12):3810-3820.

134. Haase VH. Pathophysiological consequences of HIF activation: HIF as a modulator of fibrosis. Ann N Y Acad Sci. 2009;1177:57-65.

135. McLennan SV, Abdollahi M, Twigg SM. Con- nective tissue growth factor, matrix regulation, and diabetic kidney disease. Curr Opin Nephrol Hypertens. 2013;22(1):85-92.

136. Higgins DF, Biju MP, Akai Y, Wutz A, Johnson RS, Haase VH. Hypoxic induction of Ctgf is directly mediated by Hif-1. Am J Physiol Renal Physiol. 2004;287(6):F1223-F1232.

137. Wanner C, et al. Empagliflozin and progression of kidney disease in type 2 diabetes. $N$ Engl J Med. 2016;375(4):323-334

138. Li J, et al. Renal protective effects of empagliflozin via inhibition of EMT and aberrant glycolysis in proximal tubules. JCI Insight. 2020;5(6):e129034.

139. Chang YK, et al. Dapagliflozin, SGLT2 inhibitor, attenuates renal ischemia-reperfusion injury. PLoS One. 2016;11(7):e0158810.

140. Kimura K, et al. Stable expression of HIF-1alpha in tubular epithelial cells promotes interstitial fibrosis. Am J Physiol Renal Physiol. 2008;295(4):F1023-F1029.

141. Ohtomo S, Nangaku M, Izuhara Y, Takizawa S, Strihou C, Miyata T. Cobalt ameliorates renal injury in an obese, hypertensive type 2 diabetes rat model. Nephrol Dial Transplant. 2008;23(4):1166-1172.

142. Nordquist L, et al. Activation of hypoxia-inducible factors prevents diabetic nephropathy. J Am Soc Nephrol. 2015;26(2):328-338.

143. Gu HF, et al. Impact of the hypoxia-inducible factor-1 $\alpha$ (HIF1A) Pro582Ser polymorphism on diabetes nephropathy. Diabetes Care. 2013;36(2):415-421.

144. Hill $\mathrm{P}$, et al. Inhibition of hypoxia inducible factor hydroxylases protects against renal ischemia-reperfusion injury. J Am Soc Nephrol. 2008;19(1):39-46.

145. Chavez JC, Almhanna K, Berti-Mattera LN. Transient expression of hypoxia-inducible factor-1 alpha and target genes in peripheral nerves from diabetic rats. Neurosci Lett. 2005;374(3):179-182.

146. Rojas DR, Tegeder I, Kuner R, Agarwal N. Hypoxia-inducible factor $1 \alpha$ protects peripheral sensory neurons from diabetic peripheral neuropathy by suppressing accumulation of reactive oxygen species. J Mol Med (Berl). 2018;96(12):1395-1405.

147. Geiss LS, Li Y, Hora I, Albright A, Rolka D, Gregg EW. Resurgence of diabetes-related nontraumatic lower-extremity amputation in the young and middle-aged adult U.S. population. Diabetes Care. 2019;42(1):50-54.

148. Sunkari VG, et al. Hyperbaric oxygen therapy activates hypoxia-inducible factor 1 (HIF-1), which contributes to improved wound healing in diabetic mice. Wound Repair Regen. 2015;23(1):98-103.

149. Botusan IR, et al. Stabilization of HIF-1alpha is critical to improve wound healing in diabetic mice. Proc Natl Acad Sci U S A. 2008;105(49):19426-19431.

150. Andersson T, et al. Mortality trends and cause of death in patients with new-onset type 2 diabetes and controls: a 24-year follow-up prospective cohort study. Diabetes Res Clin Pract. 2018;138:81-89.

151. Palumbo PJ, Elveback LR, Chu C-P, Connolly DC, Kurland LT. Diabetes mellitus: incidence, prevalence, survivorship, and causes of death in Rochester, Minnesota, 1945-1970. Diabetes. 
1976;25(7):566-573.

152. Seshasai SRK, et al. Diabetes mellitus, fasting glucose, and risk of cause-specific death. $N$ EnglJ Med.2011;364(9):829-841.

153. Marfella R, et al. Myocardial infarction in diabetic rats: role of hyperglycaemia on infarct size and early expression of hypoxia-inducible factor 1. Diabetologia. 2002;45(8):1172-1181.

154.Wu L, Gunton JE. The changing landscape of pharmacotherapy for diabetes mellitus: a review of cardiovascular outcomes. Int J Mol Sci. 2019;20(23):5853.

155. Chi C, Snaith J, Gunton JE. Diabetes medications and cardiovascular outcomes in type 2 diabetes. Heart Lung Circ. 2017;26(11):1133-1141.

156. Rey S, Semenza GL. Hypoxia-inducible factor-1-dependent mechanisms of vascularization and vascular remodelling. Cardiovasc Res. 2010;86(2):236-242.

157. Huang Y, et al. Cardiac myocyte-specific HIF-1alpha deletion alters vascularization, energy availability, calcium flux, and contractility in the normoxic heart. FASEB J. 2004;18(10):1138-1140.

158. Wu R, et al. Cardiac-specific ablation of ARNT leads to lipotoxicity and cardiomyopathy. J Clin Invest. 2014;124(11):4795-4806.
159. Bohuslavova R, et al. Partial deficiency of HIF-1 $\alpha$ stimulates pathological cardiac changes in streptozotocin-induced diabetic mice. BMC Endocr Disord. 2014;14(1):11.

160. Xue W, et al. Cardiac-specific overexpression of HIF-1 $\alpha$ prevents deterioration of glycolytic pathway and cardiac remodeling in streptozotocin-induced diabetic mice. Am J Pathol. 2010;177(1):97-105.

161. Binderup ML, Jensen AM, Budtz-Jorgensen E, Bisgaard ML. Survival and causes of death in patients with von Hippel-Lindau disease. JMed Genet. 2017;54(1):11-18. 